\title{
Natural dye plants used by Dayak Iban in Sungai Utik, Kapuas Hulu, West Kalimantan, Indonesia
}

\author{
WAHDINA $^{1,3}$, DEDE SETIADI ${ }^{1, \boldsymbol{}}$, Y. PURWANTO ${ }^{2}$, IBNUL QAYIM ${ }^{1}$ \\ ${ }^{1}$ Department of Biology, Faculty of Mathematics and Natural Sciences, Institut Pertanian Bogor. Jl. Agatis, IPB Dramaga Campus, Bogor16680, West \\ Java, Indonesia. Tel./fax.: +62-251-8622833, ”email: dede_setiadi@yahoo.co.id, wahdina_bot17@apps.ipb.ac.id \\ ${ }^{2}$ Research Center for Biology, Indonesian Institute of Science. Gedung Kusnoto, Jl. Ir. H. Djuanda, Bogor 16122, West Java, Indonesia \\ ${ }^{3}$ Faculty of Forestry, Universitas Tanjungpura. Jl. Prof Dr. Ir. Hadari Nawawi, Pontianak 78124, West Kalimantan, Indonesia
}

Manuscript received: 14 January 2021. Revision accepted: 21 February 2021.

\begin{abstract}
Wahdina, Setiadi D, Purwanto Y, Qayim I. 2021. Natural dye plants used by Dayak Iban in Sungai Utik, Kapuas Hulu, West Kalimantan, Indonesia. Biodiversitas 22: 1397-1404. Natural dye plants used by indigenous people in Indonesia are considered an important and unique gene pool, especially in Kalimantan (Indonesian Borneo), known to have high biodiversity and endemicity. Dayak Iban people in Sungai Utik, Kapuas Hulu District, West Kalimantan Province, Indonesia are considered a culturally important group, recognized by their customary forest and harmonious living with nature. One of the traditional knowledge practiced by this group is the use of dye plants for along time to make traditional woven fabric and various plaiting handicrafts. This study aims to investigate the types of natural dye plants used by the Dayak Iban people in Sungai Utik, and how the local people use them traditionally. Information about the dye plants used and their utilization process was obtained through in-depth interview methods. We also identified the color produced by the dye plants. There were 15 plant species used as dye plants in Sungai Utik Village. The dye plants are used for plaiting and yarn dyeing as traditional woven material with white, red, and black colors are the only colors used. The most important dye plants are engkerebai kayoh (Psychotria malayana) for red dye color and rengat kikat (Clerodendrum laevifolium) for black dye color. The coloring process includes the yarn oiling, tying, measuring, dyeing, and drying, followed by weaving process. The people in Sungai Utik obtain the dye plants in their customary forest as they keep their forests as a highly valuable treasure.
\end{abstract}

Keywords: Dayak Iban, ethnobotany, dye plant, local knowledge.

\section{INTRODUCTION}

Kalimantan (Indonesian Borneo) is one of the biggest islands in Indonesia. It harbors great plant biodiversity with high level of endemicity, making this region an important biodiversity area to conserve (de Bruyne et al. 2014; Budiharta and Meijaard 2017). Nonetheless, large-scale deforestation and land-use conversion have become the major threats to biodiversity in Kalimantan since most biological elements in the region occur in its natural tropical forest (Siregar et al. 2018; Gaveau et al. 2016). Its function is to conserve biodiversity. The natural forests in Kalimantan also provide various ecosystem services, including a large variety of forest products, water and soil conservation, microclimate regulation and air purifier, aesthetical value, etc.

Local people in Kalimantan have a long interaction with plants from generation to generation, so they are very familiar with the plant usages to meet their daily needs. The indigenous people in Kalimantan, often known as Dayak, have been using a large diversity of plant for food, herbs, medicinal purposes, building materials, condiments, etc. (Budiharta and Meijaard 2017; Royyani and Efendy 2015; Haryanti et al. 2015). Another use of plant that has been long practiced by the Dayak is for dyeing or coloring purposes. Color for local people in Indonesia, including in Kalimantan, has aesthetic value and contains deep cultural values. The use of plant materials for natural dye is relevant to the principle of harmonious living with nature long practiced by the local people in Kalimantan since synthetic dye is found to be harmful to people and the environment.

The higher cultural value of a species for the people, the easier for that people to conserve the species. However, most traditional people are currently experiencing cultural fading as the perverse outcome of modernization and globalization. There are now only few local people who understand the cultural traditions from generation to generation. Only certain people can still elaborate much about the cultural tradition, who are mostly the elderly ones with age of over 50 or 60 years old. Many young people are no longer familiar with the use of plants, including those used for dyeing or coloring purposes, due to the practicality of modern coloring agents. This situation is also worsened since the availability of plants as raw materials for dyeing and coloring products is decreasing with some of the plants are difficult to find in the wild (Joni et al. 2016; Dewi et al. 2016; Muflihati et al. 2018). Therefore, in plant conservation, principle 3 IT (Save It, Study It and Use It) is very relevant to preserve the existence of the plant resources in nature by saving, studying, and using them. Another IT principle (Manage It) would also be beneficial in order to guarantee sustainable management of the plant of interest.

Sungai Utik hamlet (dusun) is a traditional hamlet in Kapuas Hulu District, West Kalimantan, in which its local community still uses dye plants in its traditional handicraft 
products, such as woven cloth and woven rattan. The people living here are dominated by the Iban Dayak people who generally practicing land farming or agriculture and utilizing the forest nearby. Sungai Utik is also known as an ecotourism area that still preserves its land and maintains its traditional indigenous way of life. The people of Sungai Utik are defending their customary forest from land conversion to oil palm plantations. Therefore, in 2019 the Sungai Utik people, represented by their customary chief, Apai Janggut, received Kalpataru, an award as an environmental fighter from the Indonesian government and also an international award, Equator Prize.

The knowledge of the Dayak Iban people in Sungai Utik about dye plants is very interesting information considering the role of this community in maintaining their customary forests and their important role as one of the ecotourism destinations in Kapuas Hulu, West Kalimantan. This study aims to investigate the types of natural dye plants used by the Dayak Iban people in Sungai Utik, and how the local people use them traditionally.

\section{MATERIALS AND METHODS}

\section{Study area and period}

This study was performed from November 2019 to February 2020 in Sungai Utik hamlet, Batu Lintang Village, Kapuas Hulu District, West Kalimantan Province, Indonesia (Figure 1). In this area, there is a customary forest belonged to the Dayak Iban Sungai Utik indigenous people which was recognized by the Indonesian Ministry of Environment and Forestry through Decree No. 3238/MENLHK-PSKL/PKTHA/PSL.1/5/2020 on May 20, 2020. This customary forest covers 9480 ha, consisting of protection forest (Hutan Lindung/HL) with 3862 ha, limited production forest area (Hutan Produksi Terbatas/HPT) with 5518 ha, and other uses area with 100 ha. Besides the forest, the people of Sungai Utik also manage agricultural lands to produce food and other subsistence needs.

\section{Procedures}

Information about the dye plants used and their utilization process was obtained through an in-depth interview technique from room to room and walk-in-woodinterview, mainly in Sungai Utik as a weaving ecotourism area Kapuas Hulu District, West Kalimantan. Respondents for the in-depth interviews were Sungai Utik Village residents who still use dye plants in their production processes. The respondents were selected using the snowball sampling technique and the key respondents were the traditional elders and the chief of Sungai Utik. Overall, there were 12 respondents or about $40 \%$ of the total weavers in Sungai Utik. The data were collected from indepth and walk-in-wood interviews. The questions were asked about the kind of dye plants, dye plants' availability in nature, dye plant colors produced, coloring process, and the use of dye plants for coloring.

The dye plant was determined its local name by local plant identifiers. The plant was also photographed and prepared for herbarium to be identified as its Latin name using relevant literature (Ristoja 2012). The stained product samples were documented and recorded. The produced color was documented in daylight or using the flash when it was photographed at night. (Konica Minolta 2007).

\section{Data analysis}

The results of the questionnaire and in-depth interviews were descriptively analyzed with simple statistics. The color produced from the dye plant was characterized using the Pantone Color Chart in daylight to obtain a standard color. The color codes were provided using the Pantone Color Chart through an online download (Pantone.comcolor finder).

\section{RESULTS AND DISCUSSION}

\section{The people and land management in Sungai Utik}

The people of Sungai Utik in Kapuas Hulu consist of Dayak Iban people. About 43 households inhabit the Rumah Betang as a traditional house of the Dayak tribe in Kalimantan. This longhouse consists of many bilik (chambers) that are connected under one roof. Each bilik is inhabited by one or two families, containing the core family members and their close relatives. As an ecotourism village, each bilik has a guest reservation facility in a prepared room. The Hamlet Head (Kepala Dusun) must agree upon the reservation arrangements and one person as the women's representative.

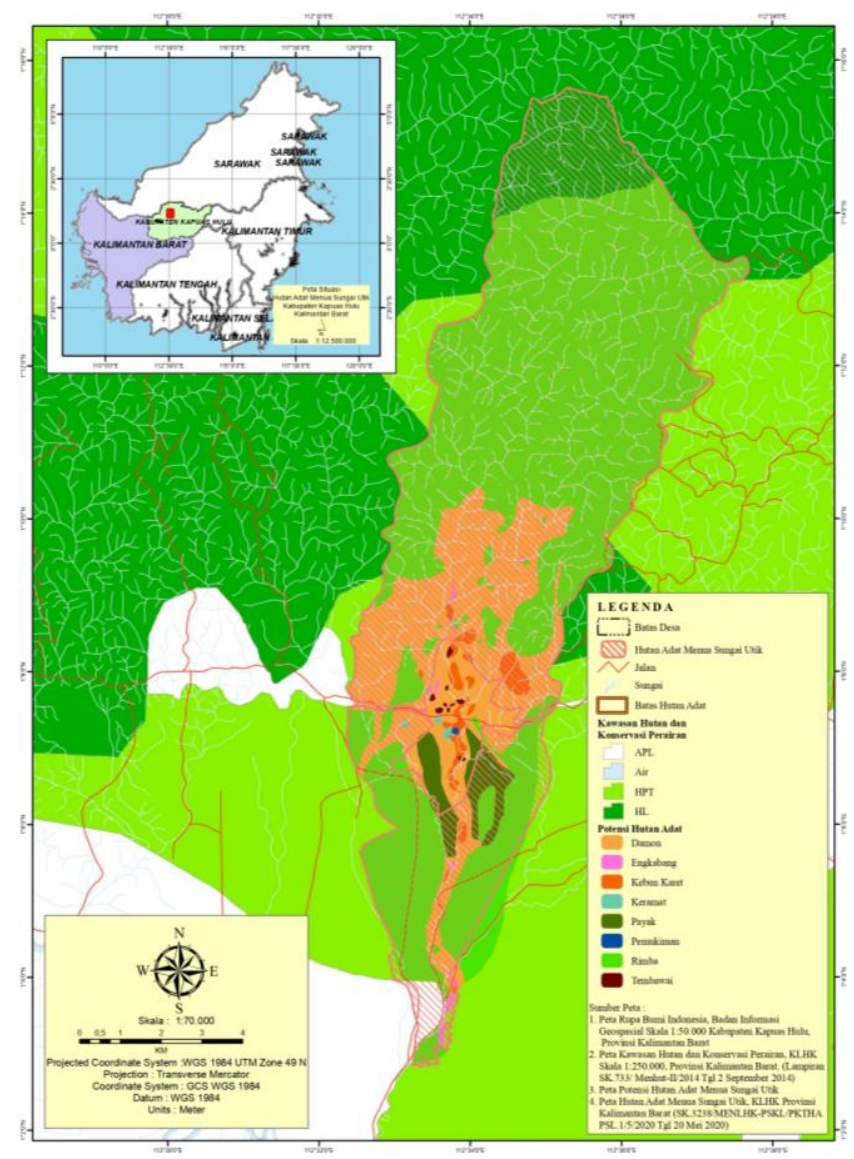

Figure 1. Map of study location in Sungai Utik, Batu Lintang Village, Kapuas Hulu District, West Kalimantan, Indonesia 
The area of Sungai Utik based on the land use type is divided into several groups, namely damun, danau, engkabang, kebun karet, keramat, payak, pemukiman, rimba, and tembawai (Table 1). This land-use information is presented in a participatory map of Sungai Utik people. Damun (fallow land) is a former farming area abandoned to regrowth. Danau (lake) is water body consisting of freshwater. Engkabang is an area dominated by tengkawang or dipterocarp tree species. Kebun karet or rubber plantation is an area mainly dominated by rubber trees (Hevea brasiliensis). There are also keramat or the sacred areas, which are commonly the ancestor cemetery. Apart from being the ancestor cemetery, the sacred area is also intended to protect the forest because the keramat area must remain undisturbed. Payak is swamp area with a lower muddy soil surface. Pemukiman or settlements is the center of people living and activities, consisting of the Betang house and other small houses. Rimba is primary forest with native vegetation and no or minimal human disturbances. Tembawai (agroforest or mixed garden) is an area consisting of mixed trees; some of which are in the protected forest areas, and others are around the settlements. Tembawai is mainly dominated by fruit trees, including various durians. The natural dye plants are generally taken from the rubber plantation, tembawai, engkabang, and rimba areas.

During the nugal or rice cultivation period, the people do not do activities related to dyeing and weaving. The nugal period lasts about 3-4 weeks; from the end of the dry season to the beginning of the rainy season. After finishing nugal, the people will wait until the rice grows to a height of 2 jengkal $(1$ jengkal $=22.86 \mathrm{~cm})$, and the traditional event is held to open the taboo for dyeing and weaving activities. Dye plant species

The Dayak Iban people in Sungai Utik use dye plants to color the woven fabrics and rattan plaitings (Figure 2). For woven fabrics, the cotton yarn is dyed. For plaitings, rattan (Calamus spp.) and resam stem (Dicranopteris linearis) are colored to make various household items and knick-knacks, such as rings and bracelets. The Dayak Iban Sungai Utik people also make mats from bemban (Donax canniformis) and perupuk (Pandanus tectorius) plants. The bemban mats remain undyed as only intended for daily use. The perupuk mats are for sale and dyed with artificial dyes. The dyed materials are often made for special purposes, such as traditional cultural events or sales. The four types of plants for woven materials are also utilized by the Dayak Tamambaloh people in Kapuas Hulu as materials for local handicraft products (Yoese et al., 2019). In Sintang, the Dayak Desa people in Ensaid Panjang betang use more than 10 plants for plaiting crafts, and they recognize more than 10 species of rattan, but a few rattan species are not found in their vicinity (Dewi et al. 2016).

Table 1. The land use classification utilized by the Dayak Iban people in Sungai Utik, Kapuas Hulu, West Kalimantan

\begin{tabular}{lcc}
\hline Land use name & $\begin{array}{c}\text { Area width } \\
\text { (ha) }\end{array}$ & $\begin{array}{c}\text { Relative percentage } \\
(\mathbf{\%})\end{array}$ \\
\hline Damun & 2094.0 & 22.1 \\
Engkabang & 33.6 & 0.4 \\
Payak & 279.3 & 2.9 \\
Tembawai & 14.1 & 0.1 \\
Kebun karet & 161.3 & 1.7 \\
Rimba & 6732.2 & 71.0 \\
Keramat & 12.0 & 0.1 \\
Pemukiman & 153.5 & 1.6 \\
Total width & 9480.0 & 100.0 \\
\hline
\end{tabular}

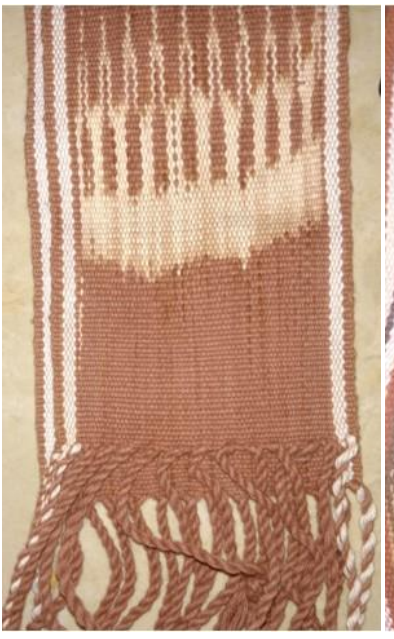

A

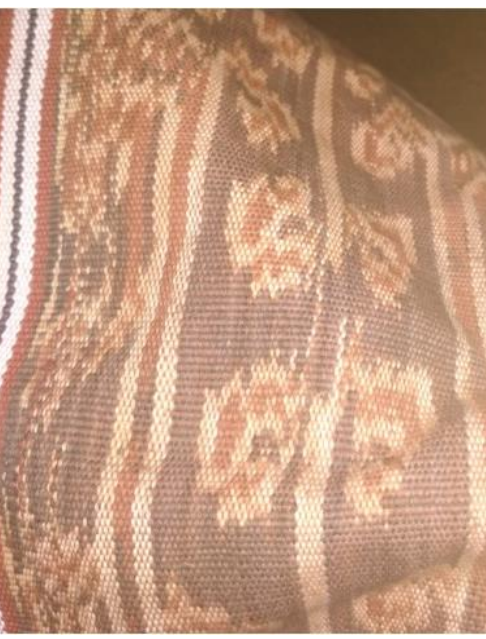

B

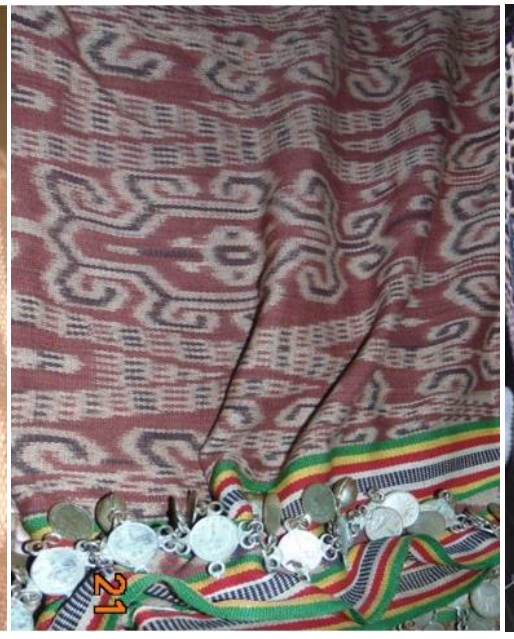

C

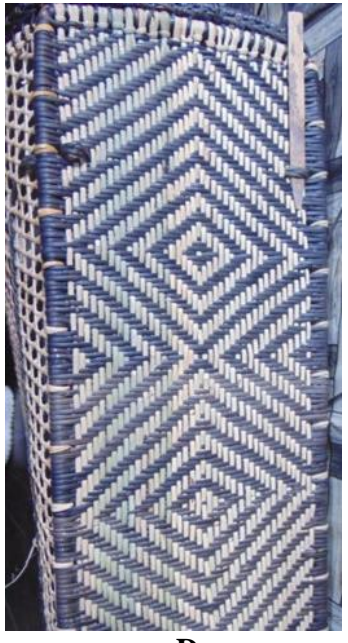

D

Figure 2. Some local products made by indigenous people in Sungai Utik that use plant as natural dyeing and coloring agents: A. Yarn colored by engkerebai kayoh (Psychotria malayana) leaves ('red', 478 C), B. Yarn colored by engkerebai kayoh (Psychotria malayana) (red, $159 \mathrm{C}$ ) and rengat kikat (Clerodendrum laevifolium) leaves (black, $4715 \mathrm{CP}$ ), C. Yarn colored by jangau bark, engkudu (Morinda citrifolia) root (red, $4100 \mathrm{CP}$ ) and rengat kikat (Clerodendrum laevifolium) leaves (black, $4294 \mathrm{CP}$ ), D. Rattan colored by manyam (Glochidion lutescens) leaves (black, 439 C). The numbers in parentheses' are the Pantone color codes. 


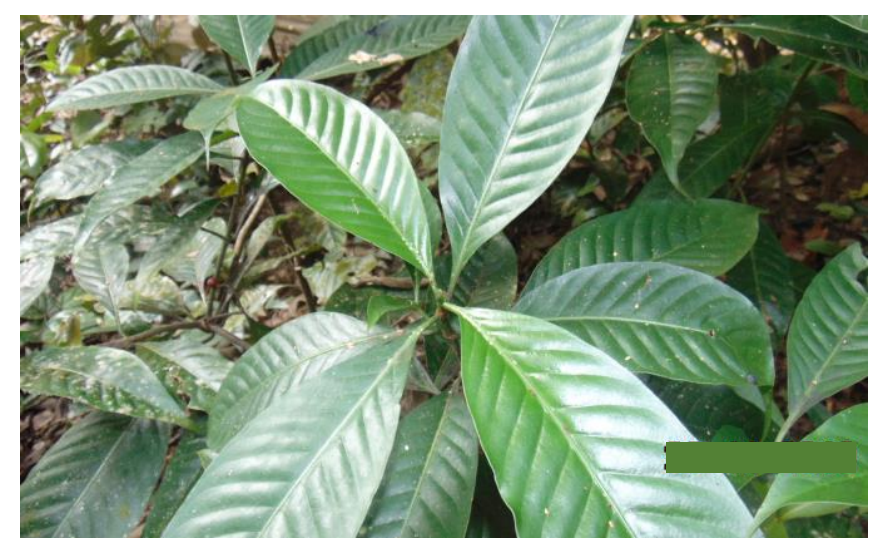

A

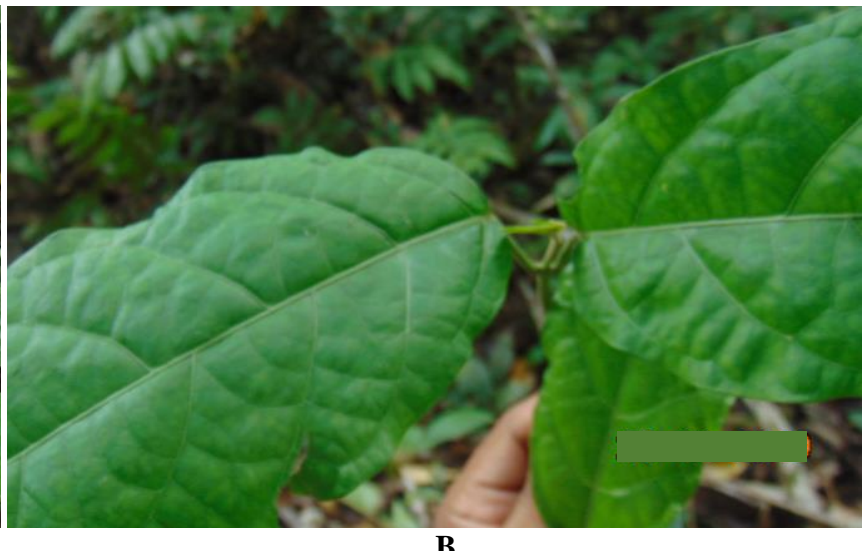

B

Figure 3. Two of the dye plants used by Sungai Utik people for yarn dyeing. A. Engkerebai kayoh (Psychotria malayana, Rubiaceae) produces red color (PMS 1797), and B. Rengat kikat (Clerodendrum laevifolium, Lamiaceae), produces bluish-black color (PMS 539)

The Dayak Iban people in Sungai Utik recognize 15 species of dye plants used for traditional handicrafts, especially for weaving (Table 2). Most of the dye plants are trees or perennial plants. Several dye plants are only used for woven yarn dyeing, while other species can be used both for weaving or plaiting. Most of the dye plants are the leaves $(53 \%)$ as the most abundant part of a plant that is available anytime.

The most preferred dye plant for weaving is engkerebai kayoh (Psychotria malayana, Rubiaceae) which produces a red color (Figure 3.A). Engkerebai kayoh plant is a bush that can easily grow in nature and is widely available around the fields and forests among the understory plants. This plant has single oblong leaves in decussated arrangement with tapered leaf base tip, and strikingly pinnate leaf venation. The leaves are arranged contradictory onto each other (decussate), just like most Rubiaceae family plants. The fruit is small and glossy red or dark red when ripe. This plant is not cultivated intensively and likely spread by birds. The Sungai Utik people recognize this plant very well; when they find the sprouts of the plant, they will leave them to grow and remain uncut. The people also state that this plant could easily sprout and branch again if the branches were cut.

The people also use rengat kikat (Clerodendrum laevifolium, Lamiaceae) to produce the bluish-black color (Figure 3.B). The leaves produce a blue color, and according to some respondents, these leaves can be combined with the engkerebai kayoh leaves to obtain the purplish-black color. This rengat kikat plant is a herb plant with single pinnate leaves arranged contradictory, distinctive venation, and the edges of the leaves are slightly wavy. This plant is semi-cultivated by the people in the specific sites of the vicinity and forest areas around the Rumah Betang.

Table 2. Dye plants used by Dayak Iban people of Sungai Utik, Kapuas Hulu.

\begin{tabular}{|c|c|c|c|c|c|c|}
\hline Local name & Scientific name & Family & Color & Part of plant used & $\begin{array}{l}\text { Kind of } \\
\text { product } *)\end{array}$ & Life-form \\
\hline Bungkang & Syzygium polyanthum & Myrtaceae & Black & Leaves & B & Tree \\
\hline Beting & Litsea $\mathrm{sp}$. & Lauraceae & Red & Bark & A & Tree \\
\hline Engkerebai kayoh & Psychotria malayana & Rubiaceae & Red & Leaves & $\mathrm{B}, \mathrm{A}$ & Bush \\
\hline Engkerebai laut & Peristrophe sp. & Acanthaceae & Red & Leaves & B & erb \\
\hline Entemu & Curcuma sp. & Zingiberaceae & Yellow & Rhizomes & B & Herb \\
\hline Jambu melaban & Psidium guajava & Myrtaceae & Brown & Leaves & B & Tree \\
\hline Jangau & Not known yet & - & Red & Bark & B & Tree \\
\hline Medang balong & Actinodaphne glomerata & Lauraceae & Red & Bark & B & Tree \\
\hline Engkudu & Morinda citrifolia & Rubiaceae & Red & Root & $\mathrm{B}, \mathrm{A}$ & Tree \\
\hline Menuang & Not known yet & - & Black & Bark & A & Tree \\
\hline Manyam & Glochidion lutescens & Phyllantaceae & Black & Leaves & $\mathrm{B}$ & Tree \\
\hline Rengat kikat & Clerodendrum laevifolium & Lamiaceae & Black & Leaves & B & Herb \\
\hline Rengat padi & Indigofera suffruticosa & Fabaceae & Black & Leaves & $\mathrm{B}, \mathrm{A}$ & Bush \\
\hline Sibau & Nephelium cuspidatum & Sapindaceae & Black & Leaves, husks & $\mathrm{B}, \mathrm{A}$ & Tree \\
\hline Ulin & Eusideroxylon zwageri & Lauraceae & Reddish-brown & Wood & $\mathrm{B}$ & Tree \\
\hline
\end{tabular}




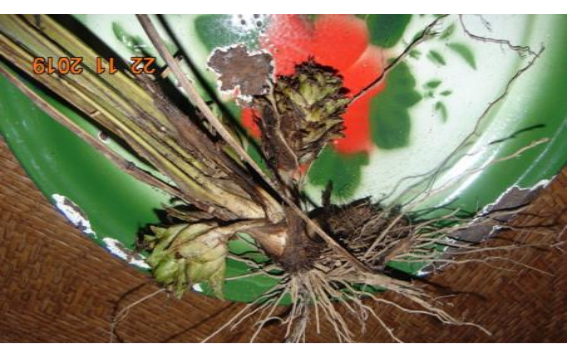

A

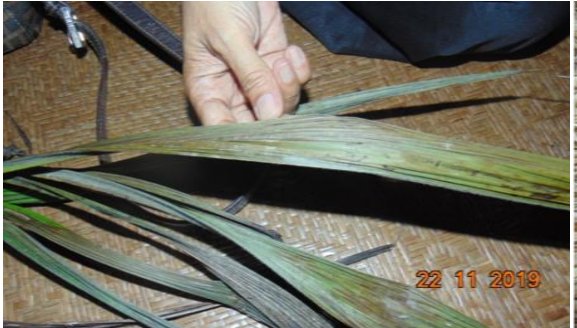

B

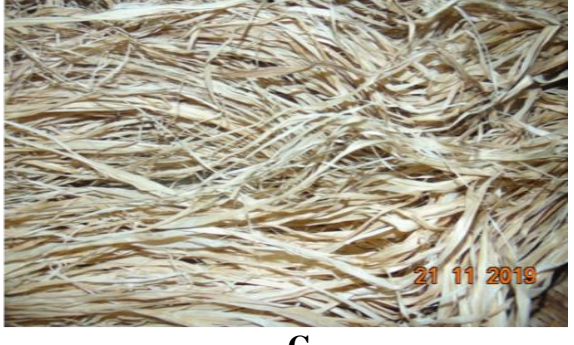

C

Figure 4. The lemba plant used for tenun ikat in Sungai Utik Village in Kapuas Hulu, A. The root, flowers, and fruits, B. Leaves, C. Lemba string used for tenun ikat dyeing process

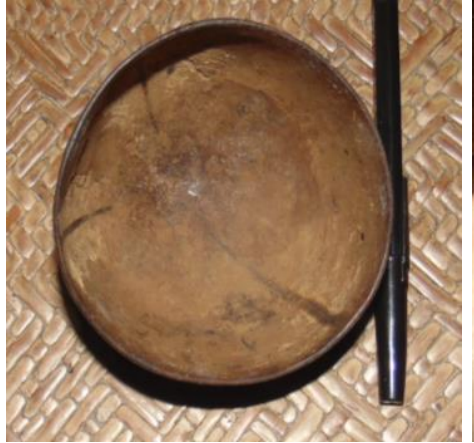

A

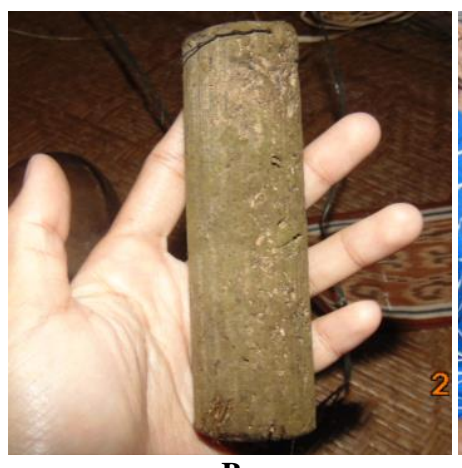

B

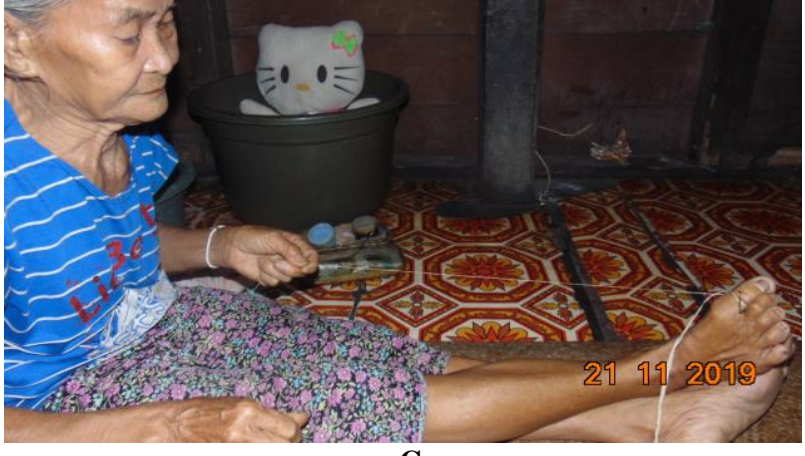

C

Figure 5. A. The nakar cup made of coconut shell, B. Stalk made of wax for measuring the dye plant ingredients, C. An elder woman shows how to make lemba string

The yarn coloring process is performed by tying a specific part of the yarn following a certain pattern. The string used for yarn tying is made from the lemba plant (Curculigo latifolia). Therefore, the Dayak Iban weaved handicraft is called 'tenun ikat' or 'tied woven yarn' (Figure 4). The yarn tying is performed before the dyeing process. In Sungai Utik, the tying pattern in the dyeing process is taught vertically from generation to generation and horizontally within the weaving groups. Recently, several weavers tried to use raffia string instead of lemba string, but they found that the pattern was ruined, which was thought due to the elasticity and plasticity of the raffia and lemba strings were different. The raffia string did not absorb water in the dyeing process, therefore the colored pattern in the yarn was not the same as expected.

The lemba string production process is fairly long, starting from harvesting the lemba plant (C. latifolia), splitting the lemba leaves, leaf fiber processing by scraping, soaking, and drying, until becoming ropes, which tied into bundles and hung on the wall for further usage. One lemba leaf usually produces 4-6 pieces of robust rope. Each bilik has this lemba string bundle for various daily uses. Many lemba plants grow on the river banks and near fields. Some people have tried to grow this plant around the house to be easily harvested. The people recognize the difference between the lemba (C. latifolia) and lemba sengkumang plant which cannot be made into a rope due to short and weak fibers, and not as elastic as the lemba plant. There were two variants of $C$. latifolia, namely the long and the short leaves (Raden et al. 2017). It appears that lemba sengkumang defined by the people is those lemba plants with short leaf stalks, which are not suitable for making ropes. The long lemba stalks have stronger and longer fiber tissue. These longer fibers are thought to be made into the string by the local people.

\section{Dyeing process}

In the past, the yarn dyeing process by Dayak Iban in Sungai Utik used a certain ritual. The yarn is soaked with a special mixture as yarn oiling. The mixture is made of liak (Zingiber officinale) rhizome, kepayang (Pangium edule) fruit, salt, liak-betuang (Zingiber sp.), engkuas (Alpinia sp.), and entemu (Сигсита sp.) rhizome, and coconut oil that are crushed together into a white concoction. Each ingredient is measured using a coconut shell called a nakar cup (Figure 5).

The kepayang fruit is initially cooked in a hot water or ignited until black with a good aroma when pounded. Each material is measured and distributed into the pounder. Then the coiled yarn is soaked into this concoction to make the yarn pores open and easily absorb the dye ingredients. After soaked for three days and three nights, the yarn is moved on a mat and taken to the river to be washed and disposed of the soaking pulp. The soaking pulp is milky white, and it must be washed until clean and no longer milky. After that, the yarn is moved into a takin (a kind of woven basket that hangs on the head and extends to the back). When all the yarns are in the takin, then the mat can be coiled. In these stages, the people who perform the dyeing process are not allowed to wear any clothes or 
trousers but must wear specific traditional cloth. In the past, there was also a ritual of wasting offerings on the stairs and in the river before starting the washing and dyeing stages. Nowadays, such rituals are no longer performed completely, but the oiling process is still performed.

After lifted from the river, the coiled yarn is dried in the sun by hanging them on long bamboos placed on poles in the front yard of the Rumah Betang, similar way to drying clothes. The coiled yarns are dried in the sun for three days and nights and must be protected from the rain to make the yarn oil absorb the dye properly. The yarn should be completely dried, otherwise, the yarn would smell bad. In the past, women who dyed the yarn must not fall asleep to keep the yarn dry.

The plant ingredients are prepared freshly or dried in the dyeing process depending on the plant species and the plant part used. The engkerebai kayoh (Psychotria malayana) and rengat kikat (Clerodendrum laevifolium) leaves are prepared freshly, and so the engkudu (Morinda citrifolia) root, manyam (Glochidion lutescens) leaves, sibau (Nephelium cuspidatum) leaves, and menuang bark. Jangau bark is used in dry form and must keep in the airand-water-tight-bottle condition to keep it for a long time. The jangau bark in a small proportion can make a good red color when mixed with engkudu root. For dyeing, the engkudu roots and jangau bark are crushed and mixed. This mixture is carried out in a large wooden tub about $2 \mathrm{~m}$ in diameter and used to soak the yarn in the dyeing process after boiled for a few hours. The mixture of engkudu root and jangau bark will dye the yarn with a red color, which cannot use too much lime to produce a bright red color. A long time ago, the Sungai Utik people still used self-made lime of snail or tengkuyung shells taken from the river. Commonly, the snails were caught in large quantities to obtain the shells, which were placed on a hot stove until becoming a white powder used as lime for the dyeing mixture. The coiled yarns are immersed in this dye mixture, heated and soaked for three nights to make the colors absorbed and evenly distributed. To test whether the color is sufficient, a porcupine quill or a bamboo stick is soaked into the dyeing tub. When the porcupine quill or the bamboo stick turned into the color expected (red or blue or black depending on the dye ingredient used), then the dye color is sufficient. Otherwise, if the color is insufficient, it is fixed by adding more dye ingredients and the soaking processes are repeated. After the dyeing is finished, the yarn is let completely dried in the sun for a few days.

To dye rattan and perupuk for mats and plaits, manyam (Glochidion lutescens) leaves, sibau (Nephelium cuspidatum) leaves and husks, are used together with the menuang bark to produce black color, and the engkerebai (Psychotria malayana, Peristrophe bivalvis) leaves are used singly to produce a red color. Rengat leaves are also good for black rattan dye according to the respondents, and rengat kikat (Clerodendrum laevifolium) leaves produce better black color than rengat padi (Indigofera suffruticosa) leaves. The rengat plant is intensively cultivated by the Dayak Iban people in Sungai Utik, especially the rengat kikat plant that is difficult to grow on their own. After the plant material is boiled in the rattan dyeing process, the cleaned and rolled rattan are tied into bundles and soaked in boiling water for dye, and soaked for three days and three nights. The amount of dye plant material is adjusted to the available rattan material. Commonly, a tuft of rattan requires about $1-2 \mathrm{~kg}$ of dye plant material.

There are differences between the dyeing process of rattan and yarn. In the yarn dyeing process, the local people use pre-treatment for the yarn by soaking it in the oiling concoction. The Dayak Desa people of Sintang also performed this kind of oiling process, and they called the process "ngaos" (Muflihati et al. 2019). The people also add the lime as the mordanting process into the dye solution. In the rattan dyeing process, the rattan is pretreated physically by scraping it, and the mordanting process is performed by soaking the scrapped rattan into the dye solution mixed with the clay or mud. The dye plant ingredients are mixed with soil, soaked overnight to produce more black dye color. Soaking can be in a bucket or by digging a hole in the slightly damp soil. Dry soil does not produce good dye color. Discussed the mud or clay is an effective dye adsorbent (Kausar et al. 2018). The combination of mud dyeing and tannin of plants made the black dye formed of iron of the mud reacting with the plants' tannin (Limaye et al. 2012).

Nowadays, many people prefer artificial dyes that are more practical and produce brighter colors. Nevertheless, yellow and black colors in the handicrafts still need natural dyes. Yellow dye color can be obtained from turmeric and entemu (Zingiber sp), while black dye color uses manyam (Glochidion lutescens) leaves or sibau (Nephelium cuspidatum) bark and fruit.

\section{Discussion}

The knowledge of local people about dye plants is unequal across Kapuas Hulu District, West Kalimantan, either among different locations and among individuals in one location. Commonly, the people who understand the dye plant species and the dyeing process are the elderly, while the youth or teenagers are only few. The elders understand these conditions because they still use the dye plants and carry out the dyeing process for years. The youths also understand because they participate in these activities to earn additional income by following their parents or family. Understandably, not all people in the community have time and passion to weave or plait. In the past, everyone had to complete the whole of their subsistence, including the weavings and plaitings. However, as the population increased, these skills become special skills.

In general, the yarn dyeing process is performed through several stages, namely yarn oiling, yarn tying, dye ingredient measuring, yarn dyeing, and drying. Yarn oiling is performed to open the yarn pores to easily accept and absorb dyes. The Dayak Iban people of Sungai Utik use a mixture of kepayang fruit and several Zingiberaceae rhizomes, as a few weavers cultivate these plants near their bilik or their field. 
Yarn tying is performed to obtain the desired pattern in the yarn. The tying pattern has been taught by the people of Sungai Utik Village from generation to generation, but it has also been done horizontally among the weavers at this time. Traditional tying patterns still use ropes made of lemba plant (Curculigo latifolia) that were widely grown around the vicinity of the settlement and on the river banks.

The next stage is dye preparation. The dye plants are prepared in a certain amount, and the people of Sungai Utik calculate the need for the dye ingredient based on their ratio to the number of yarn using a tool called nakar. The dyeing process then follows the nakar process continued with the drying yarn process. This traditional process in the Dayak Iban ikat weaving was also completely conveyed by Hidayati (2017).

Red and black are the common colors among the most preferred. Red is used for custom events as the basic color. It appears that the red color (mansa, in Dayak Iban language) ranges from red to brownish-red. The engkerebai kayoh produces the color (Psychotria malayana) leaves as the most commonly known red dye color. All respondents recognize the engkerebai kayoh leaves (Psychotria malayana, Rubiaceae) as a plant that also produces a red color. The part of the engkerebai kayoh used is the leaves. The jangau bark was also known well by the Sungai Utik weaver, pounded together with the engkudu root to make red. The engkudu root is also commonly known as a red dye for weaving in several locations in Kapuas Hulu (Santa 2015; Berlin 2016; Kartini 2017; Hidayati 2017) and Sintang (Muflihati et al. 2019). The red pigment content of the engkudu root is due to the presence of morindin (Lemmens and Soetjipto 1992). The Dayak Desa people in Sintang, West Kalimantan also use the leaves of Psychotria megacoma for dyeing the woven yarn. The Dayak Desa people in Sintang call this plant engkerebang, which is used together with the leaves of gambier (Uncaria sp.) and the addition of alum or tawas (Muflihati et al. 2019). A few Dayak Iban people in Sungai Utik also grow gambier on their field, but for medicinal purposes and not for dyeing purposes.

Totally there are 15 plant species used as dye plants in Sungai Utik. They use the dye plants for plait and yarn dyeing for tenun ikat (tied woven fabric). Traditionally, they only use three colors, namely white, red, and black. The coloring process includes the yarn oiling, tying, measuring (nakar), dyeing and drying, followed by weaving process. The differences between the yarn and rattan dyeing processes are in the starting treatment and dyeing treatment. The most important dye plant are engkerebai kayoh for red dye and rengat kikat for black dye. People in Sungai Utik obtain some of the dye plants in their customary forest, and they keep their forest as their highly valuable treasure.

\section{ACKNOWLEDGEMENTS}

This study was a part of the Doctoral Dissertation Research funded by the Indonesian Ministry of Research, Technology, and Higher Education/National Research and
Innovation Agency in 2020. The authors would like to thank the local government of Kapuas Hulu District, and especially the people of Sungai Utik, Kapuas Hulu for their welcoming and assistance, along with the field team, i.e.: Shela, Suhadi, Deni, Iqbal, Purwanti and Aden.

\section{REFERENCES}

Raden I, Nugroho CC, Syahrani. 2017. Identification and characterization of morphological diversity of Lemba (Curculigo latifolia) in East Kalimantan. Biodiversitas, 18: 1367-1376. DOI: 10.13057/biodiv/d180412

de Bruyn M, Stelbrink B, Morley RJ, Hall R, Carvalho GR, Cannon CH, van den Bergh G, Meijaard E, Metcalfe I, Boitani L, Maiorano L, Shoup R, Von Rintelen T. 2014. Borneo and Indochina are major evolutionary hotspots for Southeast Asian biodiversity. Syst Biol 63 (6): 879-901. DOI: 10.1093/sysbio/syu047.

Siregar PG, Supriatna J, RH Koestoer, Harmantyo D. 2018. System Dynamics Modelling of Land Use Change in West Kalimantan, Indonesia. Biotropia, 25 (2): 103-111. DOI: 10.11598/btb.2018.25.2.792

Muflihati, Wahdina, Kartikawati SM, Wulandari RS. 2019. Tumbuhan pewarna alami untuk tenun tradisional di Kabupaten Sintang dan Kabupaten Sambas Kalimantan Barat. Media Konservasi 24 (3): 225236. [Indonesian]

Santa EK, Mukarlina, Riza Linda, 2015. Kajian Etnobotani Tumbuhan yang Digunakan Sebagai Pewarna Alami Oleh Suku Dayak Iban Di Desa Mensiau Kabupaten Kapuas Hulu. Protobiont 4 (1) : 58-61. [Indonesian]

Muflihati, Wulandari RS, Wahdina. 2018. Natural Dye Plants for Woven Fabrics in Sambas Regency, West Kalimantan, Indonesia. In: Proceedings of The 4th Asia Future Conference. Sekiguchi Global Research Association (SGRA), Tokyo.

Lemmens RHMJ, Wulijarni-Soetjipto N (eds). 1992. Plant Resources of South-East Asia No.3. Dye and Tannin-producing Plants. PROSEA, Bogor.

Yusuf M, Shabbir M, Mohammad F. 2017. Natural Colorants: Historical, Processing and Sustainable Prospects. Nat Prod Bioprospect 7: 123145. DOI: $10.1007 / \mathrm{s} 13659-017-0119-9$.

Budiharta S, Meijaard E. in press. 2017. State of Kalimantan's biodiversity. In: Resosudarmo BP, Imansyah MH, Napitupulu L. (eds). Development, Environment and the People of Kalimantan. Indonesian Regional Science Association (IRSA), Jakarta.

Gaveau DLA, Sheil D, Yaen H, Salim MA, Arjasakusuma S, Ancrenaz M, Pacheco P, Meijaard E. 2016. Rapid conversions and avoided deforestation: examining four decades of industrial plantation expansion in Borneo. Sci Rep 6: 32017. DI: 10.1038/srep32017.

Joni A, Oramahi HA, H Adrian. 2015. Etnobotani masyarakat Dayak Suru' Studi kasus Dusun Sungai Tengkuyung Desa Tangai Jaya kecamatan Mentebah Kabupaten Kapuas Hulu. J Hutan Lestari. 3 (4): 617-624. [Indonesian]

Dewi AP, NS Ariyanti, EB Walujo. 2016. Diversity of Plants Used for Plaited Crafts by the Dayak Iban-Desa in Kabupaten Sintang, Kalimantan Barat, Indonesia. Reinwardtia. 15 (2) :67-79. DOI: 10.14203/reinwardtia.v15i2.2941

Yoese MB.B R, Dina Setyawati, Muflihati. 2019. Jenis tumbuhan hutan yang dimanfaatkan sebagai bahan kerajinan oleh Suku Dayak Tamambaloh Desa Labian Kecamatan Batang Lupar Kabupaten Kapuas Hulu. J Hutan Lestari 7 (3) : 1254-1263 [Indonesian]

Hidayati A. 2017. Ritual Tenun Ikat Pua Kumbu dalam Budaya Wanita Iban. Jurnal Visualita 6 (1): 2014. DOI: 10.33375/vslt.v6i1.1048.

Kausar A, Iqbal M, Javed A, Aftab K, Nazli ZH, NawazBhatti H, Nouren S. 2018. Dyes adsorption using clay and modified clay: A review. J Mol Liquids 256: 395-407.

Berlin SW, Linda R, Mukarlina. 2017. Pemanfaatan tumbuhan sebagai bahan pewarna alami oleh suku Dayak Bidayuh di Desa Kenaman Kecamatan Sekayam Kabupaten Sanggau. Protobiont. 6 (3): 303309. DOI: 10.26418/protobiont.v6i3.22499. [Indonesian]

Limaye MV, Bacsik Z, Schütz C, Dembelé A, Pléa M, Andersson L, Salazar-Alvarez G, Bergström L. 2012. On the role of tannins and iron in the Bogolan or mud cloth dyeing process. Textile Res J 82 (18): 1888-1896 
KonicaMinolta. 2007. Precise Color Communication. Konica Minolta Sensing, Inc. Jepang. http://konicaminolta.com/instruments/about/network.

Kartini DE, Sisillia L. 2017. Jenis tumbuhan pewarna alam yang dimanfaatkan pleh masyarakat penenun Desa batu Lintang Kecamatan Embaloh Hulu Kabupaten Kapuas Hulu. J Tengkawang 7 (2) : 84-91. DOI: 10.26418/jt.v7i2.23773 [Indonesian]

Saikhom JD, Salam JS, Potshangbam KS, Choudhury MD, Maibam HD. 2013. Biochemical studies in several dye yielding plants. Not Sci Biol 5 (3): 303-308. DOI: $10.15835 /$ nsb539078
Haryanti ES, Diba F, Wahdina. 2015. Etnobotani Tumbuhan berguna oleh masyarakat sekitar kawasan KPH Model Kapuas Hulu. J Hutan Lestari 3 (3): 434-445. DOI: 10.26418/jhl.v3i3.11370. [Indonesian]

Royyani MF, Efendy O. 2015. Kajian etnobotani masyarakat Dayak di Desa Tau Lumbis, Kabupaten Nunukan, Propinsi Kalimantan Utara, Indonesia. Berita Biologi 14 (2): 177-185. DOI: 10.14203/beritabiologi.v14i2.1852. [Indonesina] 